African Journal of Sustainable Agricultural Development | ISSN: 2714-4402

Vol. 1, Number 4 (October-December, 2020) | www.ijaar.org/ajsad

Journal DOI: 10.46654/2714

\title{
PERCEPTION OF SUDANO-SAHELIAN'S PEOPLE ON DESERTIFICATION AND ITS PROCESS
}

\author{
*EZEH F. C ${ }^{1}$. AND OGWO P. A. ${ }^{2}$ \\ ${ }^{1}$ Lagos State University, Lagos, Nigeria \\ ${ }^{2}$ Michael Okpala University of Agriculture, Umudike, Nigeria \\ *Corresponding Author: felixcezeh2020@ gmail.com
}

\begin{abstract}
Desertification is a major challenge for the people of the Sudano-Sahelian. Some of its effects on Sudano-Sahelians include hunger arising from a degraded soil, absence of portable water and general poverty. Incidentally, the action of humans has been implicated as major causative factors of desertification. Therefore, this study aimed to investigate if the bearers of the burden of desertification are the major causes of the problem. Zamfara state was randomly picked from among the eleven frontline states that fall within the Sudano-Sahelia region. Applying the Taro Yamen's formula, 500 farmers comprising 50 large scale farmers and 450 small scale farmers were selected and interviewed using a structured questionnaire. Data were computed using SPSS version 20, while correlation and regression analyses were applied to test the hypothesis as regards significant relationship between desertification and the perception of the people. The results indicated no significant relationship $(p>0.054)$ between desertification and the perception of the people. In conclusion, though the people are aware that their activities impacted desertification but are handicapped in terms of possessing the resources to fight it. Hence, they continued with their way of life and thereby aggravating an already bad situation.
\end{abstract}

Keywords: Desertification, perception, handicap, farmers, aggravating 


\section{Introduction}

Desertification is common in arid, semiarid and dry sub-humid lands. Its effects result from poor soil moisture, which makes it difficult for crops to thrive, and by implication, affects grazing animals. By implication too, this has affected the very existence of the people who are largely reliant on these crops and animal for their sustenance and survival. Various studies have shown that desert encroachment or expansion has been a common occurrence since 1908 through the early70s and even the $80 \mathrm{~s}$. Within this period, aridity was said to have been so severe than any other decade in the period before it (Abaji et al., 2013; Olatunde, 2012). While they all confirmed the decreasing annual rainfall, Ati et al. (2007) observed however that from mid 1990s, an increasing annual rainfall has been recorded. Several Authors have reported the pattern, extent and effects of natural and anthropogenic factors on desertification. For instance, Guo et al. (2011), Geist and Lambin (2004), and Gbahobo (2011) implicated man and his lifestyle as major causative factors of desertification. The same studies showed that the deleterious effects of desertification were borne by the same man. This observation could be simply referred to as their perception. Perception is a way in which something is regarded, understood or interpreted. Hartfield (2001) defined it as a means of an awareness of something, whether one's own thoughts and feelings, one's social surroundings, a business opportunity, the way to solve a mathematical problem or the current spatial layout. Kendra (2019) identified 7 steps in the perceptual process. These are: Environmental stimulus; the attended stimulus; the image on the retina; the transduction; the neural processing; perception; recognition, and action. Homel (2001) explained that perception and action are interdependent. He explained further that interaction between them appear in: Reflexes where stimuli trigger reactions that, again, affect perception, and Action planning which consists of selecting anticipated action, consequences or goals, integrating their cognitive representations and initiating the planned action either directly or by specifying environmental trigger. Witt et al. (2010) posits that action-specific perception favours the notion that perception involves processes that relate the environment to the perceiver's potential for action. In other words that action should result only when the perceiver has the potential for action.

In his strive to solve his economic problems, man has continually increased the chances of desertification (Brahic, 2007). Over cultivation, over grazing, excessive irrigation, deforestation, and urbanization, adversely impact the ability of the land to capture and hold water. Thus causes land degradation leading to desertification. The situation is being aggravated by the increase in human population, which appears to be stretching the natural support system beyond limits, in their quest for survival.

The Sudano-Sahelian zone refers to the area embedded in the Sudan savanna, Sahel Savanna or both. The word Sahel derives from the Arabic word "sahil" meaning coast or shore. This is in reference to the appearance of the Sahel region that is consistent with what is found around seashores (a sea of sand). It is largely found in Africa as a transition between the Sahara Desert and the Sudan savanna. The Sudan savanna, on the other hand, extends from the margins of the sahelien region to the guinea savanna. The area covered by the Sahel and Sudan savannas is what is referred to as the Sudano-Sahel Region. The Sudano-Sahel stretches from the Atlantic Ocean in the West to the Red sea in the east. It covers most of the southern parts of some northern 
African countries, Central African countries and northern parts of some West and East African countries. The Sudano-Sahelien region has a tropical semi-arid climate with its lowest temperature put at about $18^{\circ} \mathrm{C}$ and the highest at over $50^{\circ} \mathrm{C}$. Its annual precipitation is generally below $600 \mathrm{~mm}$. The rainy period is between 5 months in the Southern Sudan savannah and 3 months in the northern Sahel area while its dry season spans anywhere between 7 and 9 months (Adeaga, 2002; Kandji et al., 2006).

In Nigeria, twelve of the nineteen northern states are either entirely or partially in the SudanoSahelien region. These are: Kebbi, Sokoto, Zamfara, Katsina, Kano, Jigawa, Bauchi, Gombe, Yobe, Borno, Adamawa and Kaduna states. The affected states all have the climatic characteristics identified with the Sudano-Sahel region. With the exception of Kaduna state, the rest eleven are designated frontline states (by the Federal Ministry of Environment) in recognition of the extent of Sahara Desert encroachment in those areas. Although the lands in the Sudano-Sahel region are marginal, cropping and animal farming still take place in the area. It is to be expected that, as efforts are made to maximize the use of available and useable land, over cropping and over grazing of even the marginal lands would be the order of the day (Kenga et al., 2003; Fasona and Omojola, 2005).

It may therefore not be enough to know that the peoples' lifestyle causes desertification. It is more important to understand why the people who bore the hardship are the same people who contribute to desertification. The determination of this is the thrust of this paper.

\section{MATERIAL AND METHOD}

\section{Study Area:}

Zamfara state (Figure 1a) is in the North Western zone of Nigeria. It is located between latitude $12^{0} 10^{\prime} \mathrm{N}$ and longitude $6^{0} 15^{\prime} \mathrm{E}$. It is bounded by Katsina state to the east, Niger Republic to the North, Sokoto and Kebbi states to the west and Niger and Kaduna States to the south. Zamfara state has an average rainfall of between 200 and $750 \mathrm{~mm}$ per annum. It has four major rivers namely: Ka, Bunsuru, Gagare and Zamfara. It also has some lakes prominent among which are: Jena, Saru, Bakura and Dangulsi.

It has two major seasons. There is the rainy season that spans from June to October and the dry season, with whirlwind, which lasts from November to May. Its vegetation is a hybrid of Sudan Savannah and Northern Guinea Savannah. It has a temperature that could be as high as $38^{\circ} \mathrm{C}$ $\left(100.4^{0} \mathrm{~F}\right)$ between March and May (cometonigeria.com).The geology of Zamfara state shows that it is rich in granite, which forms part of its landscape. It has hills that could be as high as 200 meters. There are tertiary sediments that have resulted in limestone, clay, graphite and coal. It has its administrative headquarters in Gusua. As shown in figure $1 \mathrm{~b}$, there are fourteen local government areas namely: Anka, Bakura, Birnin Magaji, Bakkuyum, Bungudu, Tsafe. Gummi, Gusua, Kaura Namoda, Maradun, Maru, Shinkafi, Talata Mafara and Zurmi. Like every other state in Nigeria, Zamfara State has three senatorial districts namely: Zamfara East, Zamfara West and Zamfara Central Districts. By the 2006 national population census, the state has a population of 3.6 million dominated by hausas, fulanis and other smaller tribes. It has an area of about $40 \mathrm{~km}^{2}$. The economy of Zamfara state is largely agrarian with over $80 \%$ of its population 
involved in agriculture. There are other economic activities found in the area. These include commerce, textile, industrial outfits and mining.

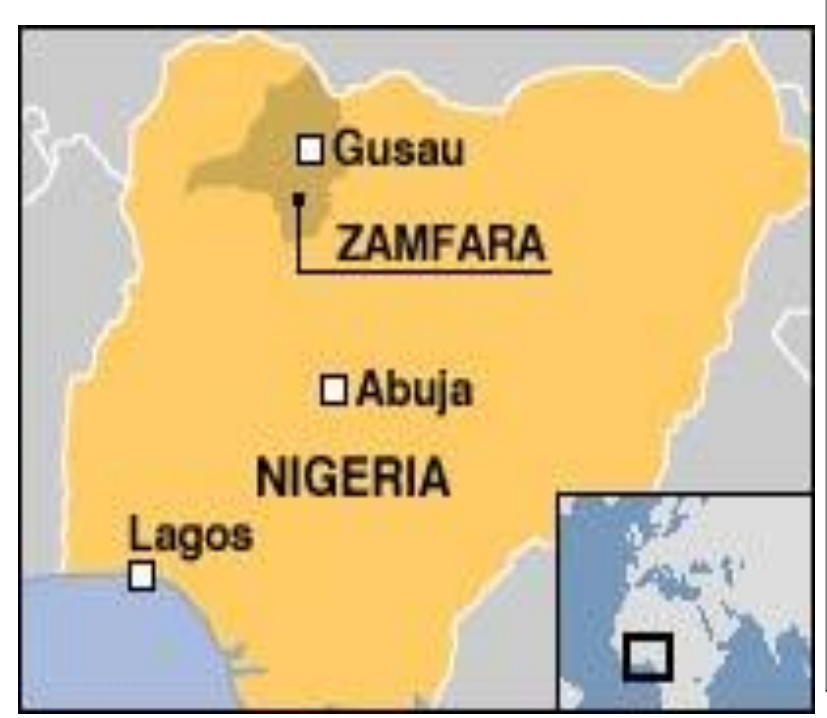

Fig 1a: Map of Zamfara

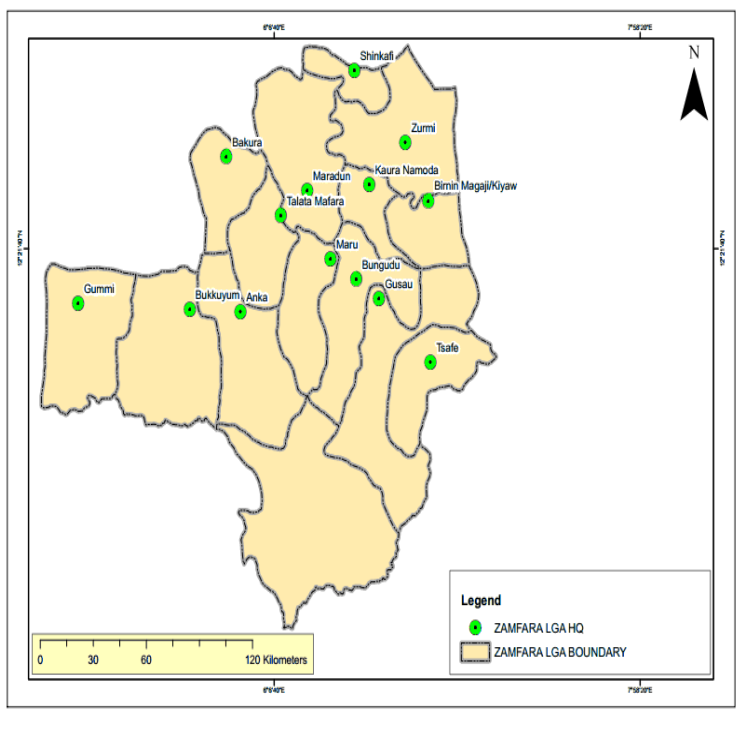

Fig 1b: Local Government Areas in Zamfara Source: www.news.bbc.co.uk/2/hi/5396176.stm

\section{Research Design and Sampling}

The nature of this study demanded the use of correlational and survey designs. Correlational design was used to examine the relationship between causes (perception) and effect (desertification). The study also employed the survey research design since it seeks to examine the status of only a cross section of farmers.

The population of the study, for the survey segment, comprises all registered farmers in Zamfara State. This includes the large and small-scale farmers. Since almost every farmer is registered with the state ministry of agriculture, for the purposes of farm input distribution, the number of each category of farmers in each local government area was easily retrieved from the ministry of agriculture. The farmers, who directly bore the effects of desertification in their everyday activities, provided assessment of perception and impact of desertification.

The sample size used for the survey study was determined by applying Taro Yamen's formula to the population obtained from the ministry of agriculture. The formula states that, given a population $\mathrm{N}$, the appropriate sample size could be determined thus:

$\mathrm{n}=\mathrm{N} / 1+\mathrm{e}^{2}$

Where $\mathrm{n}=$ sample size

$\mathrm{N}=$ population size

$\mathrm{e}=$ maximum acceptable margin of error (usually 0.05 )

$1=\mathrm{a}$ theoretical constant. 
During this study, there are forty thousand, six hundred and forty-eight $(40,648)$ registered farmers in Zamfara state. Out of this, there are four thousand and six (4006) large-scale farmers. Thus Applying Taro Yamen's formula: three hundred and ninety-six (396) was obtained as sample size.

In order to plan ahead against all respondents that might not be cooperative coupled with the need to reduce the standard error; the sample size was increased to five hundred (500). This population was distributed to Local Government Areas in proportion to the number of registered farmers they have, using the stratified sampling technique. All fourteen local government areas were covered.

Therefore, since 500 represent $1.2 \%$ of $40648,1.2 \%$ of total farmers in each local government area were selected for the exercise.

Given that the number of large-scale farmers is $10 \%$ of the registered farmers, the constitution of respondents per Local Government Area is 10\% large-scale farmers and 90\% small-scale farmers. This balancing was necessary to ensure that sampling was not biased towards either the large or small-scale farmers. Simply, it was to ensure proper representation of the different categories of farmers.

\section{Collection of Data}

A total of five hundred structured questionnaires (fifty to large-scale farmers and four hundred and fifty to small scale farmers) were administered to the selected respondents. The administration of the instrument was carried out by the researcher and assisted by well-trained fourteen assistants. These assistants were drawn from among the extension agents in the state. They are grounded in the local language and, in some cases, well known to the respondents.

To achieve instrument validity, experts drawn from among (1) psychologists (2) economists (3) educationists (4) environmentalists (5) scientists (6) and (7) agriculturists were consulted. The correlation coefficient was found to be high when a pilot study was conducted. Hence, the questionnaire was therefore confirmed reliable for the exercise.

The questionnaire has two main sections namely; section A which helped draw out the personal data of the respondents and section B, which had fixed alternative answers to the questions. In addition to these, interview of the farmers was employed to complement/clarify responses from respondents.

The instrument is further segmented into six sections namely: Assessment/determination of the extent of Desertification (from the point of view of the victims), Agricultural Practices, Incidence of Poverty, Energy Source, Farm Stability/mobility and Perception/Awareness of the causes of desertification. Largely, these, directly or indirectly, constitute the anthropogenic factors that impact the desertification process. Respondents chose from four alternative answers.

The questionnaire items were measured on a four-point Likert-type scale of Strongly Agree, Agree, Disagree and Strongly Disagree. The scoring was from 4 to 1 point for positive items 
while the reverse of 1 to 4 point for negative items. This will convert the scale to a ratio scale from nominal scale. In designing the instrument, a deliberate effort was made at balancing the positive items with the negative items. In other words, they each had about $50 \%$ share of all the items on the instrument.

For a positive item, for instance, if he chose the third column, "disagree", as it pertains to the assessment of the impact of desertification, it means his estimation of the impact is 7.5 points. For a negative item, the same third column would mean an impact of 5 points. To reduce bias, the scores are further converted to percentages for all sections. Therefore, the scores for any section, under each local government area represent the mean (percentage) score of the scores by all the participating respondents, for that section, in that local government area expressed as a percentage of the maximum scoreable point.

\section{Data Analysis}

Data collected from the survey were analyzed using both descriptive and inferential test statistics. Descriptive statistics used include means and standard deviation in addition to percentages, tables and charts. On the other hand, inferential statistics of Simple/Stepwise Regression Analyses and Pearson's Product Moment Correlation Coefficient analysis were used to test stated hypotheses of the study. The regression equation used was of the following nature:

$\mathrm{Y}=\mathrm{a}+\mathrm{b} 1 \mathrm{x} 1+\mathrm{b} 2 \mathrm{x} 2+\ldots+\mathrm{bnxn}$

Where $\mathrm{Y}=$ Dependent variable (Desertification)

$\mathrm{a}=$ regression constant (the intercept).

$\mathrm{b}=$ regression coefficient.

$\mathrm{x}=$ Independent variables.

\section{Results}

A total of 497 farmers out of the 500 selected responded to the questionnaire. These were 49largescale farmers and 448 small scale farmers. The distribution is as shown in Table 1. Bungudun and Anka LGAs had the highest (5387) and lowest (997) respective population of farmers in the study. 
Table1: Distribution of Respondents by Local Government Areas in Zamfara State, Nigeria

\begin{tabular}{|l|l|l|l|l|l|l|l|}
\hline LGA & $\begin{array}{l}\text { LARGE-SCALE } \\
\text { FARMERS } \\
\text { SAMPLE }\end{array}$ & $\begin{array}{l}\text { SMALL-SCALE } \\
\text { FARMERS } \\
\text { SAMPLE }\end{array}$ & \multicolumn{2}{l|}{$\begin{array}{l}\text { TOTAL } \\
\text { SAMPLE }\end{array}$} & $\begin{array}{l}\text { TOTAL } \\
\text { FARMER } \\
\text { POPULATION }\end{array}$ \\
\hline GIVEN & $\begin{array}{l}\text { RETUR } \\
\text { NED }\end{array}$ & GIVEN & $\begin{array}{l}\text { RETUR } \\
\text { NED }\end{array}$ & GIVEN & $\begin{array}{l}\text { RETU } \\
\text { RNED }\end{array}$ & \\
\hline ANKA & $\mathbf{1}$ & 1 & 13 & 13 & 14 & 14 & 997 \\
\hline BAKURA & $\mathbf{3}$ & 3 & 26 & 26 & 29 & 29 & 2338 \\
\hline B/MAGAJI & 4 & 4 & 33 & 32 & 37 & 36 & 3156 \\
\hline BUKKUYUM & 4 & 4 & 38 & 38 & 42 & 42 & 3472 \\
\hline BUNGUDUN & 6 & 6 & 59 & 58 & 65 & 64 & 5387 \\
\hline GUMMI & 4 & 4 & 32 & 32 & 36 & 36 & 2939 \\
\hline GUSAU & 6 & 5 & 50 & 50 & 56 & 55 & 4656 \\
\hline K/NAMODA & 4 & 4 & 35 & 35 & 39 & 39 & 3195 \\
\hline MARADUN & 2 & 2 & 18 & 18 & 20 & 20 & 1495 \\
\hline MARU & 4 & 4 & 40 & 40 & 44 & 44 & 3644 \\
\hline SHINKAFI & 1 & 1 & 12 & 12 & 13 & 13 & 900 \\
\hline T/MAFARA & 3 & 3 & 27 & 27 & 30 & 30 & 2390 \\
\hline TSAFE & 6 & 6 & 50 & 50 & 56 & 56 & 4658 \\
\hline ZURMI & 2 & 2 & 17 & 17 & 19 & 19 & 1441 \\
\hline TOTAL & 50 & 49 & 450 & 448 & 500 & 497 & 40648 \\
\hline
\end{tabular}

Source: Field Data, June 2013

\section{Farmers' Perception of Desertification}

Nine items are designed to draw this out. The score here represents how much of the processes of desertification the farmers know. A score of 60, for instance, means that out of 100points of what the farmer should know, he knows 60 points.

Correlation and stepwise regression analyses on relationship between desertification and perception showed a significant negative association between desertification and perception at $r$ $=-0.087 ; \mathrm{p}=0.027$ ).

\section{Test of Hypothesis: Desertification and Sudano-Sahelian People's Perception}

As presented in Table 2, the maximum and minimum score on impact of desertification are $87 \%$ and $43 \%$ respectively while the mean was $69.30 \pm 9.47 \%$. On the other hand, score obtained for people's perception ranged from $35 \%$ to $68 \%$ as minimum and maximum respectively while the mean score was $52.07 \pm 7.08 \%$.

The correlation and regression analysis were presented in Table 3 and 4 respectively. At $r=-$ $0.087, \mathrm{p}=0.027$, the pearson's correlation showed a significant negative relationship between desertification and people's perception of desertification in the study area. Thus, as perception increases, the process of desertification is slowed down. Similarly, a simple regression analysis 
with desertification (dependent variable) against perception (independent variable), showed that at $p=0.054$, the effect of people's perception on desertification is not significant in the process of desertification.

Table2: Descriptive statistics with respect to desertification and peoples' perception

\begin{tabular}{|l|l|l|l|l|l|}
\hline Parameter & Minimum & Maximum & Mean & $\begin{array}{l}\text { Standard } \\
\text { Deviation }\end{array}$ & Variance \\
\hline Desertification & 43.00 & 87.00 & 69.3058 & 9.47615 & 89.797 \\
\hline Perception & 35.00 & 68.00 & 52.0684 & 7.07644 & 50.076 \\
\hline
\end{tabular}

Table 3: Correlation Analysis

\begin{tabular}{|l|l|l|l|}
\hline & & Desertification & Perception \\
\hline Pearson & Desertification & 1.000 & -.087 \\
Correlation & Perception & -.087 & 1.000 \\
\hline Sig.(1-tailed) & Desertification & & .027 \\
& Perception & .027 & \\
\hline $\mathrm{N}$ & Desertification & 497 & 497 \\
& Perception & 497 & 497 \\
\hline
\end{tabular}

Table 4: Regression Analysis Coefficients

\begin{tabular}{|l|l|l|l|l|l|l|l|l|l|}
\hline & \multicolumn{2}{|l}{$\begin{array}{l}\text { Unstandardized } \\
\text { Coefficients }\end{array}$} & $\begin{array}{l}\text { Standardized } \\
\text { Coefficients }\end{array}$ & \multicolumn{2}{l|}{ Correlations } & \multicolumn{2}{l|}{$\begin{array}{l}\text { Collinearity } \\
\text { Statistics }\end{array}$} \\
\hline Model & $\mathbf{B}$ & $\begin{array}{l}\text { Std } \\
\text { Error }\end{array}$ & Beta & $\mathbf{t}$ & Sig. & $\begin{array}{l}\text { Zero- } \\
\text { order }\end{array}$ & $\begin{array}{l}\text { Parti } \\
\text { al }\end{array}$ & Tolerance & VIF \\
\hline Constant & 75.340 & 3.151 & & 23.911 & .000 & & & & \\
\hline Perception & -.116 & .080 & -.087 & -1.933 & .054 & -.087 & -.087 & 1.000 & 1.000 \\
\hline
\end{tabular}

\section{DISCUSSION}

In this study, there was no significant relationship between desertification and perception by the people of Sudano-Sahel as shown by the correlation analysis. This was also affirmed by the regression analysis which indicated that people's perception of the problem of desertification has no significant effect on the desertification process in the Sudano-Sahelian Region. The implication of these findings is that while perception has the potentials of assisting in the fight against desertification, it has actually not been tapped and therefore has played insignificant role in the process.

In other words, even when the knowledge could impact the fight positively, people have continued business as usual. This could be because, in the poverty-stricken position the people found themselves, they lacked the potential for action. The present result is in agreement with 
report of Witts (2010) which divulged that a perceiver's potential for action determines the action he takes against a given stimulus. Lee and Zhang (2004) also affirmed that there was a considerable divergence between experts' perception and the public's. They therefore advised that, for policy formulation, the different views must be taken into consideration.

The present findings also buttress the work of Geist and Lambin (2002) that studied the effects of desertification on tropical forests and reported that the forests were disappearing on account of pressure that are both local and regional acting in various combinations in different geographical locations. Such pressure includes the need to increase food production and infrastructural development to achieve. The findings in this study could also be because the passage of time is needed for improved knowledge of Zamfara's farmers to cause appropriate action/change of their attitude towards the fight against desertification.

It could also be that farmers have continued to do what they are familiar with unsure of how the alternative would affect them. Lee and Zhang (2004), in a survey of 1138 respondents to determine how the public's perception of desertification could be used in its control, reported that while many respondents were aware of desertification, they did not fully understand the various issues involved. Moreso, they reported that perception of desertification was affected by their personal attributes and needs.

Ephraim et al. (2011) opined that if social benefits are placed on scale with social costs at conception stage, chances are that some actions or ventures would have been aborted at that level

\section{Conclusion}

The study examined if people's perception impacted the desertification of the Sudano-Sahel region. The analyses of the survey showed that while perception had strong negative association with the desertification process, it had a negative effect on the desertification process. This outcome is certainly against common expectations. In this study, though the people are aware that their activities impacted desertification but are handicapped in terms of possessing the resources to fight it. Hence, they continued with their way of life and thereby aggravating an already bad situation.

Assisting the Sudano-Sahelian people, via training and provision of necessary resources, is crucial to fight desertification. Until that is done, it is obvious that the Sahara will continue its majestic southern march, unchallenged. 


\section{Bibliography}

Abaje, I. B., Ati, O. F., Iguisi, E. O. \& Jidauna, G. G. (2013). Droughts in the Sudano-Sahelien ecological zone of Nigeria: Implications for agriculture and water resources development. Global Journal of Human Social Sciences, Geography, Geo-Sciences and Environment, $13(2), 1$ - 10

Adeaga, O. (2002). Management of drought risk in the Sudano-Sahelian region of Nigeria. In Henry, A.J;Van Lanen \& Siegfried Demuth (Eds.), FRIENDS 2002 - Regional hydrology: Bridging the gap between research and practice (267-273). IAHS Bureau, Parisand Behavioral Sciences.

Ati, O. F, Iguisi, E. O. \& Afolayan, J. O. (2007). Are we experiencing drier conditions in the Sudano-Sahelien zone of Nigeria? Journal of Applied Sciences Research 3 (12), 1746 1751.Brahic, C. (2007). Sunshade for global warming could cause drought. Geophysical Research Letters. (D01:10.1029/2007GL030524).

Fasona, M. J. \& Omojola, A. S.(2005). Climate change, human security and communal clashes in Nigeria. Paper presented at an international workshop on Human security and climate change. Holmen Fjord Hotel, Asker near Oslo. 22-25 June 2005. Retrieved fromhttp://www.gechs.org/downloads/holman/Fasona_Omotola.pdf

Gbahobo, T. P. (2011). Desertification and rural livelihoods: A case study of Gurusulu Village, YobeState, Nigeria. An Unpublished M.Sc.Thesis. University of Witwatersrand, Johannesburg, South Africa. (Geist, H. J. \& Lambin. E. F. (2004). Dynamic causal patterns of desertification. Bioscience 54 (9), $817-829$.

Guo, M., Liu, Y., Wang, X. F., Matsuoka, N. \&Tani, H. (2011). Analysis of desertification and wood land distribution: A case study on the Balinyon Banner of Inner Mongolia, China. International Journal of Remote Sensing 33 (21) 6838 - 6853

Hatfield, G. (2001). Perception: History of Concept in International Encyclopedia of Social

Homel, B. (2001). Perception and Action in International Encyclopedia of Social and

Kandji. S. T., Verchot, L. \& Mackenson, J. (2006). Climate change and variability in the Sahel region: Impacts and adaptation strategies in the agricultural sector. World Agroforestry Centre (ICRAF) and United Nations Environment Program (UNEP). Nairobi, Kenya.

Kendra, C. (2019). https://www.verywellmind.com/cognitive-psychology-overview

Kenga R., Njoya A., M'biandoun M., Havard M. \&Vall, E. (2003). Analysis of constraints to agricultural production in Sudano-Sahelian zone of Cameroon using a diagnostic survey.

Olatunde, A. F. (2012). The intensities of wet years in the Sudano-Sahelien region of Nigeria between 1941-2008. Continental Journal of Environmental Sciences 6 (2), 44 - 53. 
African Journal of Sustainable Agricultural Development | ISSN: 2714-4402

Vol. 1, Number 4 (October-December, 2020) |www.ijaar.org/ajsad

Journal DOI: 10.46654/2714

Article DOI: 10.46654/2714.141223

Witt, J. K., Proffitt, D. R. and Epstein, N. (2010). How and When does action scale perception. Journal of Experimental Psychology. Human Perception and Performance 36, 1153-1160. 